\title{
Pengaruh Hypnobreastfeeding Terhadap Produksi ASI
}

\author{
Yopi Suryatim Pratiwi ${ }^{1)}$, Sri Handayani ${ }^{1)}$, Lalu Mariawan Alfarizi ${ }^{2}$ \\ Email: yopisuryatimpratiwi@gmail.com \\ ${ }^{1)}$ Program Studi Kebidanan Jenjang D.3, STIKes Yarsi Mataram \\ ${ }^{2)}$ Universitas Nahdatul Ulama Nusa Tenggara Barat
}

\begin{abstract}
ABSTRAK
Angka kematian bayi masih tinggi di Indonesia. 53\% disebabkan oleh faktor nutrisi. ASI eksklusif mampu menurunkan angka kesakitan dan kematian bayi. Produksi ASI kurang merupakan keluhan yang paling sering diutarakan ibu nifas dan menjadi penyebab kegagalan ASI eksklusif. Studi ini merupakan suatu tinjauan literatur yang mencoba menggali pengaruh hypnobreastfeeding terhadap produksi ASI. Review tujuh penelitian menunjukkan hypnobreastfeeding mampu meningkatkan produksi ASI. Hal ini disebabkan hypnobreastfeeding membuat ibu lebih relaks, tenang fisik, pikiran, dan nyaman selama masa menyusui sehingga dapat memberikan positif feedback mechanism berupa respon peningkatan pelepasan oksitosin dan prolaktin oleh pituitari. Hormon prolaktin berperan dalam merangsang zat gizi untuk sintesis air susu dalam sel-sel sekretorius alveoli. Oksitosin menyebabkan kontraksi mioepitel di sekeliling alveolus dan mengeluarkan air susu.
\end{abstract}

Kata Kunci: air susu ibu, hypnobreastfeeding

\begin{abstract}
Infant mortality is still high in Indonesia. 53\% is caused by nutritional factors. Exclusive breastfeeding can reduce infant morbidity and mortality. Breastmilk production is less a complaint that is most often expressed by postpartum mothers and is the cause of exclusive breastfeeding failure. This study is a literature review that attempts to explore the influence of hypnobreastfeeding on breast milk production. A review of seven studies shows hypnobreastfeeding can increase milk production. This is because hypnobreastfeeding makes the mother more relaxed, calm physically, mindfully, and comfortably during breastfeeding so that it can provide a positive feedback mechanism in the form of a response to increased release of oxytocin and prolactin by pituitary. The prolactin hormone plays a role in stimulating nutrients for the synthesis of milk in the cells of the alveoli secretory. Oxytocin causes myoepithelial contractions around the alveoli and secretes milk.
\end{abstract}

Keywords: breastmilk, hypnobreastfeeding

\section{A. LATAR BELAKANG}

Angka kematian merupakan salah satu indikator kesehatan yang penting dan mencerminkan derajat kesehatan di suatu wilayah. Angka Kematian Bayi (AKB) di Indonesia periode 2007-2012 sebesar 32 per 1.000 kelahiran hidup, Angka Kematian Neonatal (AKN) sebesar 19 per 1.000 kelahiran hidup, dan Angka Kematian Balita (AKABA) sebesar 40 per 1.000 kelahiran hidup.[1] Komitmen global dalam Millennium Development Goals
(MDGs) pada tujuan ke-4 menetapkan target terkait kematian anak, yaitu menurunkan AKB menjadi 23 per 1000 kelahiran hidup dan AKABA menjadi 32 per 1000 kelahiran hidup atau menurunkan angka kematian hingga dua per tiga dalam kurun waktu 1990-2015.[2]

Angka kematian bayi di Indonesia sebagian besar terkait dengan faktor nutrisi, yaitu sebesar 53\%. Beberapa penyakit yang timbul akibat malnutrisi antara lain pneumonia (20\%), diare (15\%), dan 
perinatal (23\%). Statistik juga menunjukkan lebih dari 70\% kematian Bayi lima tahun (Balita) disebabkan diare, pneumonia, campak, malaria, dan malnutrisi.[3]

Air Susu Ibu (ASI) eksklusif mampu menurunkan angka kesakitan dan kematian bayi.[4] Pemberian ASI secara optimal dapat mencegah 1,4 juta kematian di seluruh dunia pada Balita setiap tahun dan mengurangi kematian karena infeksi pernapasan akut dan diare 50-95\%.[5] Menyusui suboptimal menyebabkan $45 \%$ kematian neonatal karena infeksi menular, $30 \%$ kematian karena diare, dan $18 \%$ kematian karena gangguan pernapasan akut pada anak di bawah usia lima tahun di negara berkembang.[6]

ASI eksklusif adalah pemberian makan pada bayi dengan ASI saja dan tidak ada makanan tambahan, air, atau cairan lain (kecuali obat-obatan dan vitamin, jika diperlukan) selama enam bulan pertama kehidupan. ASI adalah makanan terbaik bagi bayi dan memiliki keseimbangan nutrisi yang tepat, tersedia secara biologis, mudah dicerna, melindungi bayi dari penyakit, dan memiliki sifat antiinflamasi.[7]

Capaian pemberian ASI eksklusif di Indonesia masih jauh dari target nasional sebesar $80 \%$. Persentase pemberian ASI eksklusif pada bayi 0-6 bulan di Indonesia pada tahun 2013 sebesar 54,3\%. Persentase pemberian ASI eksklusif tertinggi terdapat di Nusa Tenggara Barat (NTB) sebesar $79,74 \%$ dan terendah di Provinsi Maluku sebesar 25,21\%.[8]

Produksi ASI yang kurang merupakan keluhan yang sering diutarakan oleh ibu terutama minggu pertama nifas dan menjadi penyebab kegagalan ASI eksklusif. Penelitian di Australia menyebutkan dari 556 ibu melahirkan, 29\% berhenti menyusui bayinya pada minggu kedua dengan alasan ASI kurang. ${ }^{8}$ Hasil wawancara pada penelitian yang dilaksanakan di Rumah Sakit Bersalin (RSB) Kabupaten Sleman Yogyakarta terhadap 48 responden, $31,25 \%$ ibu menyatakan mengalami ASI kurang.[9]

Hypnobreastfeeding membantu ibu untuk memastikan agar ibu yang menyusui bisa terus memberikan ASI, minimal secara eksklusif selama enam bulan pertama.[10] Hypnobreastfeeding adalah upaya alami menggunakan energi bawah sadar agar proses menyusui berjalan dengan nyaman lancar, serta ibu dapat menghasilkan ASI yang mencukupi kebutuhan bayi. Prinsip hypnobreastfeeding dengan memasukkan kalimat-kalimat afirmasi positif untuk proses menyusui disaat ibu dalam keadaan sangat rileks atau sangat berkonsentrasi. Hypnobreastfeeding telah terbukti dapat menurunkan kecemasan ibu dan waktu pengeluaran ASI serta meningkatkan sikap ibu hamil dalam pemberian ASI eksklusif.[11],[12] Teknik ini, perubahan yang diinginkan adalah segala hal yang mempermudah dan memperlancar proses menyusui.

Berdasarkan latar belakang di atas, penulis mengambil judul artikel "Pengaruh Hypnobreastfeeding terhadap Produksi ASI".

\section{B. METODE PENELITIAN}

Studi ini merupakan suatu tinjauan literatur (literature review) yang mencoba menggali pengaruh hypnobreastfeeding terhadap produksi ASI. Sumber untuk melakukan tinjauan literatur ini meliputi studi pencarian sistematis data base terkomputerisasi (Pubmed, Pro Quest, dan google cendekia) bentuk jurnal penelitian berjumlah 20 penelitian. Penulisan artikel ini menggunakan penulisan daftar pustaka Harvard. 


\section{HASIL DAN PEMBAHASAN}

\section{a. Hasil}

Beberapa penelitian menunjukkan terhadap produksi ASI. Hal tersebut dapat dilihat pada tabel berikut:

terdapat pengaruh hypnobreastfeeding

Tabel 1 Hasil Penelitian dari Tinjauan Literatur

\begin{tabular}{|c|c|c|c|}
\hline No. & Penulis & Metode Penelitian & Hasil Penelitian \\
\hline 1. & $\begin{array}{l}\text { Anita Rahmawati } \\
\text { dan Bisepta } \\
\text { Prayogi.[13] }\end{array}$ & $\begin{array}{l}\text { Disain dalam penelitian } \\
\text { adalah one group } \\
\text { pretest posttest. }\end{array}$ & $\begin{array}{l}\text { Pemberian hypnobreastfeeding yang } \\
\text { dilakukan sendiri oleh ibu menyusui, } \\
\text { setiap hari, minimal } 2 \mathrm{x} \text { sehari sebelum } \\
\text { menyusui dengan cara mendengarkan } \\
\mathrm{CD} \text { hypnobreastfeeding mampu } \\
\text { meningkatkan produksi ASI pada ibu } \\
\text { menyusui yang bekerja dengan rata-rata } \\
\text { produksi ASI sebelum perlakuan } 210 \\
\text { ml/hari dan setelah perlakuan menjadi } \\
255 \mathrm{ml} / \mathrm{hari} \text {. }\end{array}$ \\
\hline 2. & $\begin{array}{l}\text { Diah Evawanna } \\
\text { Anuhgera, } \\
\text { Tjahjono } \\
\text { Kuncoro, Sri } \\
\text { Sumarni, } \\
\text { Mardiyono, dan } \\
\text { Ari Suwondo.[14] }\end{array}$ & $\begin{array}{l}\text { Desain dalam penelitian } \\
\text { ini adalah quasi } \\
\text { experiment dengan } \\
\text { pendekatan One group } \\
\text { Pre Test-Post Test } \\
\text { Design. }\end{array}$ & $\begin{array}{l}\text { Hasil penelitian menunjukan hipnoterapi } \\
\text { lebih efektif dalam merangsang } \\
\text { peningkatan prolaktin dan produksi ASI } \\
\text { dibandingkan dengan akupresur pada } \\
\text { ibu post Section Caesarea (SC) }\end{array}$ \\
\hline 3. & $\begin{array}{l}\text { Diyan Indriyani } \\
\text { dan Asmuji.[15] }\end{array}$ & $\begin{array}{l}\text { Penelitian ini dilakukan } \\
\text { dengan menggunakan } \\
\text { desain penelitian } \\
\text { eksperimen semu (quasy } \\
\text { experiment) dengan } \\
\text { rancangan posttest only } \\
\text { design with } \\
\text { nonequivalent groups }\end{array}$ & $\begin{array}{l}\text { Pemberian } \\
\text { hypnobreastfeeding dan konsumsi } \\
\text { blustru efektif terhadap optimalisasi } \\
\text { produksi kolostrum pada ibu } \\
\text { postpartum, dimana nilai rerata } \\
\text { kolostrum 21,93 dengan nilai minimal } \\
15 \text { dan nilai maksimal 26; sedangkan } \\
\text { produksi kolostrum pada ibu postpartum } \\
\text { yang tidak dilakukan tindakan } \\
\text { kombinasi hypnobreast-feeding dan } \\
\text { konsumsi blustru didapatkan nilai rerata } \\
\text { 15,07 dengan nilai minimal } 13 \text { dan nilai } \\
\text { maksimal } 24 \text {. }\end{array}$ \\
\hline 4. & $\begin{array}{l}\text { Lutfiana Puspita } \\
\text { Sari, Harsono } \\
\text { Salimo, dan Uki } \\
\text { Retno } \\
\text { Budihastuti.[16] }\end{array}$ & $\begin{array}{l}\text { Desain dalam penelitian } \\
\text { ini adalah analitik } \\
\text { eksperimental dengan } \\
\text { Randomized Control } \\
\text { Trial (RCT). }\end{array}$ & $\begin{array}{l}\text { Pemberian kombinasi pijat oksitosin } \\
\text { dan } \\
\text { hypnobreastfeeding efektif menurunkan } \\
\text { kecemasan dan meningkatkan produksi } \\
\text { ASI pada ibu masa nifas. }\end{array}$ \\
\hline 5. & $\begin{array}{l}\text { Yuni Nor Aini, } \\
\text { Hadi, Sri Rahayu, } \\
\text { Noor Pramono, } \\
\text { dan Donny } \\
\text { Kristanto } \\
\text { Mulyantoro.[17] }\end{array}$ & $\begin{array}{l}\text { Desain dalam penelitian } \\
\text { ini adalah quasy } \\
\text { experimental dengan } \\
\text { pretest posttest control } \\
\text { group. }\end{array}$ & $\begin{array}{l}\text { Pemberian kombinasi pijat oksitosin } \\
\text { dan } \\
\text { hypnobreastfeeding selama } 30 \text { menit, } \\
\text { dua kali sehari, pagi dan sore hari, } \\
\text { berpengaruh terhadap peningkatan } \\
\text { produksi ASI dimana tingkat prolaktin } \\
\text { pada kelompok eksperimen (273.53) } \\
\text { lebih tinggi dibandingkan kelompok } \\
\text { kontrol (209.37). }\end{array}$ \\
\hline 6. & $\begin{array}{l}\text { Putri Rahma Dini, } \\
\text { Ari Suwondo, } \\
\text { Triana Sri } \\
\text { Hardjanti, } \\
\text { Soeharyo } \\
\text { Hadisaputro, }\end{array}$ & $\begin{array}{l}\text { Desain dalam penelitian } \\
\text { ini adalah quasi } \\
\text { experiments dengan } \\
\text { pretest-posttest control } \\
\text { group design. }\end{array}$ & $\begin{array}{l}\text { Pemberian pijat oksitosin dan atau } \\
\text { hypnobreastfeeding selama } 20-30 \text { menit, } \\
\text { dua kali sehari, pagi dan sore hari, } \\
\text { selama } 4 \text { hari signifikan meningkatkan } \\
\text { produksi ASI, yaitu sebesar } 79,10 \mathrm{ml} / 2 \\
\text { kali pompa/hari, pemberian } \\
\text { hypnobreastfeeding saja }(60,51 \mathrm{ml} / 2 \mathrm{kali}\end{array}$ \\
\hline
\end{tabular}




\begin{tabular}{|l|l|l|l|}
\hline No. & \multicolumn{1}{|c|}{ Penulis } & Metode Penelitian & \multicolumn{1}{|c|}{ Hasil Penelitian } \\
\hline & $\begin{array}{l}\text { Mardiyono, dan } \\
\text { Melyana Nurul } \\
\text { Widyawati.[18] }\end{array}$ & & $\begin{array}{l}\text { pompa/hari), dan pijat oksitosin saja (53, } \\
32 \mathrm{ml} / 2 \text { kali pompa/hari), sedangkan } \\
\text { kelompok kontrol (42,18 mml/2 kali } \\
\text { pompa/hari). }\end{array}$ \\
\hline 7. & $\begin{array}{l}\text { Yuni Kusmiyati } \\
\text { dan Heni Puji } \\
\text { Wahyuningsih }\end{array}$ & $\begin{array}{l}\text { Desain dalam penelitian } \\
\text { ini adalah quasy } \\
\text { experimental. }\end{array}$ & $\begin{array}{l}\text { Hipnobreastfeeding yang dilakukan } \\
\text { dengan memberi afirmasi positif diiringi } \\
\text { lagu dari CD menunjukkan mampu } \\
\text { menurunkan kecemasan pada ibu nifas } \\
\text { dan mempercepat pengeluaran ASI, } \\
\text { dimana rata-rata skor kecemasan } \\
\text { responden pada kelompok perlakuan } \\
\text { pre-test: 8,44 post-test: 1,41, sedangkan } \\
\text { pada kelompok kontrol pre-test: 8,7 } \\
\text { post-test: 9,44, sedangkan rata-rata lama } \\
\text { pengeluaran ASI pada kelompok } \\
\text { perlakuan 13,07 jam dan pada kelompok } \\
\text { kontrol 18,43 jam. }\end{array}$ \\
\hline
\end{tabular}

\section{b. Pembahasan}

Laktasi merupakan proses produksi, sekresi, dan pengeluaran ASI.[19] Keberhasilan proses ini dipengaruhi oleh faktor nutrisi, seperti status gizi dan asupan nutrisi ibu, dan faktor non nutrisi diantaranya faktor hormonal, umur ibu, paritas, usia gestasi, kesehatan ibu dan bayi, kebiasaan ibu (perokok dan konsumsi alkohol), frekuensi menyusui, dan keadaan psiksosial ibu.[20]

Produksi ASI yang kurang merupakan keluhan yang sering diutarakan oleh ibu terutama minggu pertama nifas dan menjadi penyebab kegagalan ASI eksklusif. Produksi ASI dipengaruhi oleh banyak faktor, terutama faktor psikologi dan fisiologi (hormonal), yang memengaruhi sintesis dan sekresi, serta pengeluaran air susu.

Peningkatan produksi ASI salah satunya dapat dilakukan dengan hypnobreastfeeding. Hasil tujuh penelitian di atas (tabel 1) menunjukkan hypnobreastfeeding dan atau kombinasi hypnobreastfeeding dengan pijat oksitosin maupun konsumsi blustru, mampu meningkatkan produksi ASI.

Hypnobreastfeeding adalah upaya alami menggunakan energi bawah sadar agar proses menyusui berjalan dengan nyaman lancar, serta ibu dapat menghasilkan ASI yang mencukupi kebutuhan bayi. Prinsip Hypnobreastfeeding dengan memasukkan kalimat-kalimat afirmasi positif untuk proses menyusui disaat ibu dalam keadaan sangat rileks atau sangat berkonsentrasi.[21,22]

Teknik hypnobreastfeeding sama dengan teknik hypnobirthing karena juga melibatkan pikiran bawah sadar dengan cara mengistirahatkan alam sadar melalui teknik relaksasi. Teknik relaksasi dalam hypnobreastfeeding terdiri atas tiga tahap yaitu: 1) Ibu melakukan relaksasi otot mulai dari puncak kepala sampai telapak kaki, termasuk wajah, bahu kiri dan kanan, kedua lengan, daerah dada, perut, pinggul, sampai kedua kaki. Caranya bisa dengan membayangkan otot-otot menjadi relaksasi. 2) Relaksasi napas. Zaman sekarang orangorang rentan mengalami stres. Stres karena dituntut untuk melakukan segala sesuatu serba cepat dan terburu-buru. Apalagi, perempuan yang memiliki peran ganda sebagai seorang ibu sekaligus wanita karier. Untuk mencapai kondisi relaks adalah dengan cara tarik napas panjang melalui hidung dan hembuskan keluar pelan-pelan 
melalui hidung atau mulut (fokuskan pernapasan di perut). Lakukan selama beberapa kali sampai ketegangan mengendur dan berangsur hilang. 3) Relaksasi pikiran. Seringkali pikiran seseorang berkelana jauh dari raganya. Untuk itu, belajarlah memusatkan pikiran agar berada di tempat yang sama dengan raga. Salah satu cara dengan berdiam diri atau meditasi dengan mengosongkan pikiran dan memejamkan mata dengan napas yang lambat, mendalam dan teratur selama beberapa saat. Setelah otot-otot rileks, nafas teratur, serta pikiran tenang, baru dilakukan sesi hypnobreastfeeding.[21]

Ibu-ibu menyusui juga bisa melakukan hypnobreastfeeding di rumah, caranya mudah, masuklah ke dalam ruangan yang tenang, nyalakan musik khusus untuk relaksasi, sediakan aroma therapy, dan ikuti panduan relaksasi otot, napas, dan pikiran yang telah dipelajari sebelumnya, baru melakukan afirmasi yang positif. Pikiran bawah sadar secara otomatis akan membimbing untuk melakukan atau memikirkan hal-hal tertentu, misalnya yakin bahwa kita bisa menyusui dan ASI akan mengalir deras. Cara lain yang sederhana adalah dengan mendengarkan suara bayi serta perhatikan alur napasnya. Jika hal tersebut dilakukan secara teratur, akan menimbulkan bonding dan selanjutnya memicu tubuh untuk menghasilkan hormon endorfin (hormone pembawa rasa senang dan tenang)sehingga tubuh merasa rileks.[12]

Faktor psikis ibu (keyakinan ibu terhadap produksi ASI) merupakan faktor paling bermakna yang memengaruhi ASI eksklusif.[22] Faktor psikologis yang memengaruhi kurangnya produksi ASI adalah ibu yang berada dalam keadaan stres.[23] Keadaan emosional diatur oleh oksitosin di otak sehingga oksitosin pusat dapat berfungsi sebagai target terapi yang potensial untuk meningkatkan mood dan perilaku sosial-afiliatif pada pasien dengan defisit sosial mendalam. Oksitosin juga mampu mengekspresikan reseptor dopamin. Oksitosin dan dopamin berada pada Central Nervous System (CNS) yang sama dan sama-sama memengaruhi mood dan perilaku sosial-afiliatif.[24]

Studi pada hewan menunjukkan bahwa berbagai jenis rangsangan stres dapat menekan laktasi, sama halnya dengan pada manusia. Studi eksperimental pada wanita menyusui telah menunjukkan bahwa stres akut baik fisik dan mental dapat mengganggu reflek let-down dengan mengurangi pelepasan oksitosin selama menyusui.[25] Jika hal ini terjadi berulang kali, bisa mengurangi produksi susu dengan mencegah pengosongan penuh payudara. Studi observasional menunjukkan bahwa stres ibu dan janin selama persalinan dan melahirkan (misalnya karena SC yang mendesak, lama persalinan) berhubungan dengan tertundanya laktasi. Efek stres emosional kronis pada laktasi tidak diketahui. Ibu yang mengalami tingkat stres yang tinggi selama dan setelah melahirkan harus menerima bimbingan laktasi tambahan selama minggu pertama atau dua minggu postpartum.[26] Wanita primipara memiliki risiko stres lebih tinggi dibandingkan multipara. Wanita primipara memiliki kadar kortisol 2 kali lebih tinggi dibandingkan kadar kortisol pada wanita multipara.[27]

Bila ada stres dari ibu yang menyusui maka akan terjadi suatu blokade dari reflek let-down. Ini disebabkan oleh adanya pelepasan dari adrenalin (epinefrin) yang menyebabkan vasokontriksi pembuluh darah alveoli sehingga oksitosin sedikit harapannya untuk dapat mencapai target organ mioepitelium. Akibat dari tidak sempurnanya reflek let-down maka akan terjadi penumpukan air susu di dalam alveoli yang secara klinis tampak payudara 
membesar. Payudara yang besar dapat berakibat abses, gagal untuk menyusui, dan rasa sakit. Rasa sakit ini akan merupakan stres lagi bagi seorang ibu sehingga stres akan bertambah.[28]

Karena reflek let-down tidak sempurna maka bayi yang haus jadi tidak puas. Ketidakpuasan ini akan merupakan tambahan stres bagi ibunya. Bayi yang haus dan tidak puas ini akan berusaha untuk dapat air susu yang cukup dengan cara menambah kuat isapannya sehingga tidak jarang menimbulkan luka-luka pada puting susu dan sudah pasti luka-luka ini akan dirasakan sakit oleh ibunya yang juga akan menambah stres. Dengan demikian, akan terbentuk satu lingkaran setan (circulus vitiosus) yang tertutup dengan akibat kegagalan dalam menyusui.[29]

Ibu yang merasa tertekan/stres, produksi susu mereka harus didorong dengan menggunakan teknik relaksasi, seperti bernapas dalam, pijat lembut, memiliki sesuatu yang menyenangkan nuntuk dimakan atau diminum, dan/atau mendengarkan musik favorit mereka untuk mendorong reflek ejeksi susu.[30]

Penelitian Kusmiyati dan Heni (2014)[31] di Yogyakarta menemukan bahwa hypnobreastfeeding menurunkan tingkat kecemasan pada ibu menyusui yaitu dengan skor pre eksperimen 8,44 menjadi 1,41 pada saat post eksperimen. Oleh karena itu, hypnobreastfeeding mampu membuat ibu rilaks, tenang fisik, pikiran, dan nyaman selama masa menyusui sehingga dapat memberikan positif feedback mechanism berupa respon peningkatan pelepasan oksitosin dan prolaktin oleh pituitari.[32]

Hormon prolaktin merangsang sel-sel epitelial alveolar yang berfungsi untuk sekresi dan sintesis air susu.[33] Prolaktin menyebabkan dimulainya laktogenesis karena mengikat reseptor khusus pada permukaan membran sel epitel payudara.
Reseptor ini terdiri dari domain eksternal dan internal. Prolaktin mengaktifkan reseptor secara berurutan melalui penggabungan dua molekul yang identik (homodimerisasi), yang menyebabkan aktivasi Janus Kinasus 2 (JAK2) terkait dengan domain kinase sitoplasma. JAK2 merangsang Transducer and Activator of Transcription (STAT 5) sehingga menyebabkan proliferasi sel epitalium alveolus.[23]

Oksitosin yang dilepaskan ke sirkulasi sistemik diangkut melalui aliran darah menuju uterus yang dapat menimbulkan kontraksi pada uterus sehingga terjadi involusi dari organ tersebut.[33] Oksitosin yang sampai pada alveoli akan memengaruhi sel mioepitalium dan menyebabkan kontraksi. Kontraksi dari sel akan memeras air susu yang telah disintesis keluar dari alveoli dan masuk ke sistem duktulus. Hal ini menyebabkan peningkatan tekanan intraduktal, terjadinya pelebaran duktus, dan akibatnya terjadi peningkatan laju aliran air susu melalui duktus laktiferus masuk ke mulut bayi. Dalam waktu 30 detik sampai 1 menit setelah bayi mengisap payudara air susu mulai mengalir. Proses ini dikenal sebagai reflek let-down atau pengeluaran air susu.[28]

\section{KESIMPULAN}

Hypnobrastfeeding mampu meningkatkan produksi ASI karena memberikan efek rileks, ketenangan fisik, pikiran, dan kenyamanan pada masa menyusui yang dapat memberikan positif feedback mechanism berupa respon peningkatan pelepasan oksitosin dan prolaktin oleh pituitari. Hormon prolaktin berperan dalam merangsang zat gizi untuk sintesis air susu dalam sel-sel sekretorius alveoli. Oksitosin menyebabkan kontraksi mioepitel di sekeliling alveolus dan mengeluarkan air susu (milk ejection). 


\section{E. UCAPAN TERIMA KASIH}

Terima kasih kami ucapkan kepada para editor dan reviewer yang telah berkontribusi dengan meluangkan waktu dan mencurahkan pikirannya demi terbitnya artikel literature review ini. Saran dan kritik selalu kami harapkan demi tercapainya manfaat dari penerbitan artikel ini.

\section{DAFTAR PUSTAKA}

[1] Kementerian Kesehatan RI. Survei Demografi dan Kesehatan Indonesia (SDKI) 2012. Jakarta: Badan Penelitian dan Pengembangan Kesehatan Kementerian RI. 2012.

[2] Badan Perencanaan Pembangunan Nasional. Laporan Pencapaian Tujuan Pembangunan Millenium di Indonesia. ISBN 978-979-3764-64-1, 2011.

[3] Kementerian Kesehatan RI. Profil Kesehatan Indonesia 2013. Jakarta: Kementerian Kesehatan Republik Indonesia. 2014.

[4] Mihrshahi S, Oddy WH, Peat JK, Kabir I. Association between infant feeding patterns and diarrhoeal and respiratory illness: a cohort study in Chittagong, Bangladesh. Int Breastfeed J. 2008;3(1):23-8.

[5] UNICEF. Improving Exclusive Breast Feeding Practices by using Communication for Development in Infant and young Child Feeding Programs. 2010.

[6] World Health Organization. Global health risks: mortality and burden of disease attributable to selected major risks: World Health Organization; 2009.

[7] Mekuria G, Edris M. Exclusive breastfeeding and associated factors among mothers in Debre Markos, Northwest Ethiopia: a cross-sectional study. International breastfeeding journal. 2015;10(1):1-7.

[8] Scott J, Colin W. Breastfeeding: reasons for starting, reasons for stopping and problems along the way. Breastfeeding Review. 2002;10(2):13.

[9] Sa'roni, Sadjiman T, Sja'bani M, Zulaela Z. Effectiveness of the Sauropus androgynus (1.) Merr leaf extract in increasing mother's breast milk production. Media Penelitian dan Pengembangan Kesehatan. 2004;14(3 Sept).

[10] Andriana E. Melahirkan tanpa Rasa Sakit Dengan Metode Relaksasi Hypnobirthing. Jakarta: BIP; 2007.

[11] Astin JA, Shapiro SL, Eisenberg DM FK. Mind-Body Medicine: State Of The Science, Implications For Practice. J Am Board Fam Pract. 2003;16 (2):131-7.

[12] Kuswandi L AY. Basic Hypnosis \& Hypnobirthing. Dalam Basic Hypnosis \& hypnobirting work book; 6-8 Maret 2009. Bali, Indonesia: Pro V Clinic (Holistic Health Care); 2009. 7-55 p.

[13] Rahmawati A., Prayogi B. Hypnobreastfeeding untuk Meningkatkan Produksi Asi pada Ibu Menyusui Yang Bekerja. Seminar Nasional dan Gelar Produk, 2017.

[14] Anuhgera DE, Kuncoro T, Sumarni $\mathrm{S}$, Mardiyono $\mathrm{M}$, Suwondo A. Hypnotherapy is more effective than acupressure in the production of prolactin hormone and breast milk among women having given birth with caesarean section. Medicine Science, 2017. doi: 10.5455/medscience.2017.06.8659.

[15] Indriyani D, Asmuji. Efektifitas Kombinasi Hypnobreastfeeding dan Konsumsi Blustru terhadap Optimalisasi Produksi Kolostrum pada Ibu Postpartum di Rumah Sakit Dr. Soebandi Jember. The Indonesian Journal Of Health Science, Vol. 6, No.2, Juni 2016.

[16] Puspita Sari L, Salimo H, Budihastuti UR. Optimizing the Combination of Oxytocin Massage and Hypnobreastfeeding for Breast Milk Production among Post-Partum Mothers. Journal of Maternal and Child Health (2017), 1(1): 20-29 https://doi.org/10.26911/thejmch.2017. 
02.01.03 20 e-ISSN: 2549-0257 (online).

[17] Aini YN, Hadi, Rahayu S, Pramono $\mathrm{N}$, Mulyantoro D. Effect OF Combination of Oxytocin Massage and Hypnobreastfeeding on Uterine Involution and Prolactin Levels in Postpartum Mothers. Belitung Nursing Journal. 2017 June;3(3):213-220.

[18] Dini PR, Suwondo A, Hardjanti TR, Hadisaputro S, Mardiyono, Widyawati MN. The Effect of Hypnobreastfeeding and Oxytocin Massage on Breastmilk Production in Postpartum. JMSCR Vol. 05, Issue 10, Page 28600-28604, October 2017.

[19] Irianto, K. Gizi Seimbang Dalam Kesehatan Reproduksi. Jakarta: Alfabeta; 2014.

[20] Penagos Tabares F, Bedoya Jaramillo JV, Ruiz-Cortés ZT. Pharmacological overview of galactogogues. Veterinary medicine international. 2014;2014.

[21] Nurindra Y. Hypnotherapy Fundamental: A Journey to the Subsconscious World dalam Hypnoterapy Fundamental Workshop 6-7 Maret 2010. Bandung: Yan Nurindra School of Hypnotism; 2010. 1-31 p. 10. James T, Flores L SJ. Hypnosis: AComprehensive Guide Producing Deeptrance Phenomena. UK: Cromwel Press; 2000. 1-9 p.

[22] Fahriani R, Rohsiswatmo R, Hendarto A. Faktor yang Memengaruhi Pemberian ASI Eksklusif pada Bayi Cukup Bulan yang Dilakukan Inisiasi Menyusu Dini (IMD). Sari Pediatri. 2014;15(6):394-402 .

[23] Bachelot A, Binart N. Reproductive role of prolactin. Reproduction. 2007;133(2):361-9.

[24] Baskerville TA, Douglas AJ. Dopamine and oxytocin interactions underlying behaviors: potential contributions to behavioral disorders. CNS neuroscience \& therapeutics. 2010;16(3):e92-e123.

[25] Tops M, Van Peer JM, Korf J, Wijers AA, Tucker DM. Anxiety, cortisol, and attachment predict plasma oxytocin. Psychophysiology. 2007;44(3):444-9.

[26] Dewey KG. Maternal and fetal stress are associated with impaired lactogenesis in humans. The Journal of nutrition. 2001;131(11):3012S-5S.

[27] Grajeda R, Pérez-Escamilla R. Stress during labor and delivery is associated with delayed onset of lactation among urban Guatemalan women. The Journal of nutrition. 2002;132(10):3055-60.

[28] Geddes DT. Inside the lactating breast: the latest anatomy research. Journal of Midwifery \& Women's Health. 2007;52(6):556-63.

[29] Soetjiningsih. Seri Gizi Klinik ASI Petunjuk untuk Tenaga Kesehatan. Jakarta: EGC; 1997.

[30] Kent JC, Prime DK, Garbin CP. Principles for maintaining or increasing breast milk production. Journal of Obstetric, Gynecologic, \& Neonatal Nursing. 2012;41(1):114-21.

[31] Kusmiyati Y, Wahyuningsih HP. Pengaruh Hypnobreastfeeding terhadap Kecemasan dan Waktu Pengeluaran ASI pada Ibu Post Partum Primipara di Yogyakarta. J Teknol Kesehatan, 2014;12 No 2.

[32] Kamariyah, N. 2014. Kondisi Psikologi Mempengaruhi Produksi Asi Ibu Menyusui di Bps Aski Pakis Sido Kumpul Surabaya. Jurnal Ilmiah Kesehatan. 7(12): 29-36.

[33] Corwin, EJ. Buku Saku Patofisiologi (Handbook of pathophysiologi). Jakarta: EGC; 2001. 